2003

\title{
Blinded by Bioterrorism: Public Health and Liberty in the 21st Century
}

George J.Annas

Follow this and additional works at: https://scholarlycommons.law.case.edu/healthmatrix

Part of the Health Law and Policy Commons

\section{Recommended Citation}

George J. Annas, Blinded by Bioterrorism: Public Health and Liberty in the 21st Century, 13 Health Matrix 33 (2013)

Available at: https://scholarlycommons.law.case.edu/healthmatrix/vol13/iss1/5

This Symposium is brought to you for free and open access by the Student Journals at Case Western Reserve University School of Law Scholarly Commons. It has been accepted for inclusion in Health Matrix: The Journal of Law-Medicine by an authorized administrator of Case Western Reserve University School of Law Scholarly Commons. 


\title{
BLINDED BY BIOTERRORISM: PUBLIC HEALTH AND LIBERTY IN THE $21^{\text {ST }}$ CENTURY
}

\author{
George J. Annas ${ }^{\dagger}$
}

Ah yes, the quarantine, it didn't do any good.

José Saramago, Blindness

In Blindness, Nobel Prize laureate José Saramago chronicles the quarantining of the first victims of a plague of blindness. ${ }^{1}$ We meet many people who become blind in Saramago's novel, including an opthamologist, a one-eyed man with an eye patch, and a man born blind. Saramago reminds us that we are all blind in one way or another, and that there are many things about ourselves and our society that we can't or won't see. The quarantine itself turns out to be isolating, inhumane, and degrading; the interred blind being portrayed by themselves and others as pigs, dogs, and "lame crabs." Soldiers stand guard, and shoot anyone trying to escape, mostly out of fear that they themselves might become infected by the blindness virus.

Of course many Americans were temporarily blinded on September 11 by the smoke and debris in the terror attacks on the World Trade Center and the Pentagon. And even after the smoke cleared, fear and anger fueled a desire for revenge and a quest for security. The security quest seemed even more urgent following the anthrax attacks through the mail. Fear generated responses that in retrospect appear overzealous, potentially counterproductive, and unnecessarily destructive of human rights. This is easier to see after almost two years have elapsed since $9 / 11$, especially in the area of bioterrorism.

${ }^{\dagger}$ George J. Annas is the Edward R. Utley Professor and Chair of the Health Law Department, Boston University School of Public Health, Professor of SocioMedical Sciences and Community Medicine, Boston University School of Medicine, Professor of Law, Boston University School of Law, and cofounder of Global Lawyers and Physicians. A.B., Harvard College (1967); J.D., Harvard Law School (1970); M.P.H., Harvard School of Public Health (1972). Copyright 2003 by George J. Annas.

1 José Saramago, Blindness (Giovanni Pontiero trans., Harcourt Brace \& Co., 1998) (1995). 
In this article I examine two specific public health responses to $9 / 11$, the treatment of those exposed in the anthrax by mail attacks, and the proposal for new state antibioterrorism legislation. I suggest that our "new kind of war" on terror requires us to abandon our $19^{\text {th }}$ century vision of public health as essentially a coercion-based state and local activity, and to accept the fact that in the $21^{\text {st }}$ century public health is properly and primarily a national and international activity that should be based on human rights. It is simply not true that we must always sacrifice individual rights and liberty to take effective public health action against contagious diseases: modern public health measures must put human rights first to be effective. Finally, I will briefly examine the severe acute respiratory syndrome (SARS) epidemic of 2003 and the attempt to vaccinate some health care providers against smallpox as of way of testing the reasonableness of the conclusions drawn from our experiences with anthrax and state antibioterrorism legislation as they relate to modern public health.

\section{THE ANTHRAX ATTACKS}

In emergency situations, including war, bioterrorism, and epidemics, all sorts of decisions may be made and justified in a free society that would in normal circumstances be seen as repulsive and contrary to the constitutional foundations of the society itself. Immediately after September 11, for example, the civil liberties of suspected terrorists were suspended, secret military tribunals were proposed to try terrorists, and torture was proposed to obtain information from terrorists. ${ }^{2}$ Although we have a tendency to opt for safety over liberty, this is often a false choice that produces neither. ${ }^{3}$ In this regard the public health reaction to America's first major bioterrorist attack involving

${ }^{2}$ See, e.g., President Bush's Order on the Trial of Terrorists by Military Commission, N.Y. TIMES, Nov. 14, 2001, at B8 (authorizing secretive military tribunals); Elisabeth Bumiller \& David Johnston, Bush Sets Option of Military Trials in Terrorist Cases, N.Y. TIMES, Nov. 14, 2001, at Al (indicating the creation of military tribunals \& the loss of rights); Robin Toner, Civil Liberty vs. Security: Finding a Wartime Balance, N.Y. TIMEs, Nov. 18, 2001, at Al (discussing reduced civil liberties and the creation of military tribunals as a result of the September 11, 2001 attacks); Alan M. Dershowitz, Yes, It Should be "On the Books," Boston GloBE, Feb. 16, 2002 , at A15 (expressing his opinion against torture without legislative and judicial approval); Jeffrey Rosen, The Difficult Balance Between Liberty and Security, N.Y. TIMES, Oct. 6, 2002, $\S 4$ (Late Edition), at 13 (discussing the constitutionality of laws enacted after September 11, 2001 that allow investigation of all Americans).

${ }^{3}$ See, e.g., Benjamin Franklin, AN Historical Review of the Constitution AND Government of Pennsylvania (1759) (containing the oftquoted statement: "Those who exchange liberty for security deserve neither"). 
multiple locations in the United States, which used anthrax delivered through the mail, holds lessons for emergencies. ${ }^{4}$

Twenty-two people developed anthrax (about half inhalation and half cutaneous) from the attacks, and five died. ${ }^{5}$ More than 10,000 people were advised to take antibiotics on the presumption that they were at risk for inhalation anthrax. ${ }^{6}$ In late December, the Food and Drug Administration (FDA), the Department of Defense (DOD), and the Centers for Disease Control and Prevention (CDC) together released the anthrax vaccine, previously only available to the military, and approved by the FDA only to prevent cutaneous anthrax, for use by those exposed to anthrax in the attacks. ${ }^{7}$ Of the 10,000 people eligible to take the vaccine, only $152 \mathrm{did}^{8}$ In the face of continuing high anxiety about the possible health effects of anthrax exposure, this less than 2 percent positive response to the federal government's invitation to take the vaccine is extraordinary. CDC officials wanted to know why so few chose to take the vaccine, but reportedly decided not to survey them to find out why they refused to consent to take this investigational vaccine because the survey itself would have necessitated obtaining consent. ${ }^{9}$

We can take some comfort in the small number of casualties in the anthrax attacks. Nonetheless, the anthrax bioterrorist was extremely effective in meeting his or her goal: not mass killing (the goal in biowarfare), but terrorizing the civilian population. Since we cannot be sure that similar attacks will not occur in the future, it is impor-

4 Julie Louise Gerberding et al., Bioterrorism Preparedness and Response: Clinicians and Public Health Agencies as Essential Partners, 287 JAMA 898, 898 (2002).

5 Id.

${ }^{6}$ Id.

7 See Thomas V. Inglesby et. al., Anthrax as a Biological Weapon, 2002: Updated Recommendations for Management, 287 JAMA 2236, 2243-44 (2002) (discussing the history, benefits, and limitations of the anthrax vaccine).

${ }^{8}$ See Steve Twomey, Vaccine Offer Draws Few Postal Workers, Wash. Post, Dec. 28, 2001, at A6 (detailing the limited acceptance of the vaccine offer); see also Sheryl Gay Stolberg, Civilians Are Reluctant to Join U.S. Test of Anthrax Vaccine, N.Y. TIMES, Jan. 8, 2002 at Al3 (confirming that less than two percent of the 10,000 workers received the vaccine); Gerberding et al., supra note 4 at 899 .

${ }^{9}$ See Stolberg, supra note 8 (noting the irony of a consent requirement for a survey of why individuals chose not to receive the vaccine). See also Lawrence Altman \& Gina Kolata, Anthrax Missteps Offer Guide to Fight Next Bioterror Battle, N.Y. TIMES, Jan. 6, 2002, at Al (suggesting the steps to be taken in the event of another bioterror attack). It was later learned that only $44 \%$ of those exposed who were told to take antibiotics for 60 days actually did. Approximately 13\% took no medication at all. Lawrence K. Altman, Many Workers Ignored Anthrax Pill Regimen, N.Y. Times, Oct. 30, 2002, at A18. 
tant to understand the belated response of the federal government in making the anthrax vaccine available, and why the public rejected its use, in order to be better prepared for the next bioterrorist attack or similar public health emergency. The basic rules regarding the use of investigational drugs in biowarfare, and arguably in bioterrorism, go back to the 1991 Gulf War.

\section{INVESTIGATIONAL DRUGS IN WAR AND BIOWAR}

Just prior to the Gulf War, the Pentagon sought an FDA waiver of informed consent requirements for the use of specific investigational drugs and vaccines on U.S. troops in the Gulf. ${ }^{10}$ Informed consent is, of course, required for all human experiments, including the use of investigational drugs and vaccines. Specifically, the DOD sought waivers of informed consent under FDA rules so DOD could use an investigational drug (pyridostigmine bromide to be used as a pretreatment against an attack by the nerve gas soman), and an investigational vaccine (botulinum toxoid, a protective against clostridium botulinum) without obtaining informed consent from the soldiers. ${ }^{11}$

There is provision in the FDA regulations for waiver of informed consent when consent is not "feasible," but this exception had never before been applied to competent adults. The basis of the DOD waiver request was that informed consent was not feasible because the military mission could be compromised if individual soldiers could opt out of taking these agents. ${ }^{12}$ The FDA adopted a new regulation permitting waiver of consent for military operations, and approved the requested waivers under the provisions of the new regulation. ${ }^{13}$ The FDA did, however, require the military to make information sheets on the agents available to the troops, and to collect, review and report on adverse experiences. ${ }^{14}$

Because it was an approved drug, the military use of pyridostigmine bromide as a "pretreatment" for a gas attack could have alternatively been justified as use of an approved drug for an unapproved indication based on the argument that it was a safe drug, even if not

${ }^{10}$ For a more detailed discussion of the Gulf War waiver, see George $\mathrm{J}$. Annas, Protecting Soldiers from Friendly Fire: The Consent Requirement for Using Investigational Drugs and Vaccines in Combat, 24 AM. J.L. \& MED. 245 (1998).

"Id. at 247.

1221 C.F.R. $\$ 50.23$ (1999).

${ }^{13} \mathrm{Id}$.

${ }^{14}$ Human Drugs and Biologics; Determination that Informed Consent is NOT Feasible or is Contrary to the Best Interests of Recipients; Revocation of 1990 Interim Final Rule; Establishment of New Interim Final Rule, 64 Fed. Reg. 54,180, $54,184$ et. seq. (Oct. 5,1999$)$. 
proven effective for this particular use. ${ }^{15}$ Moreover, the military command ultimately decided to make botulinum toxoid vaccination voluntary. ${ }^{16}$ Nonetheless, the FDA's 1990 waiver-of-consent rule itself cannot be justified on the facts. Obtaining consent was feasible in the field, and failure to obtain it in the case of investigational drugs and vaccines is a direct violation of the consent requirements of the Nuremberg Code that the military had adopted as their own in $1953 .{ }^{17}$ The FDA policy also turned out to be counterproductive and dangerous. It led to a situation in which the troops were put in much more jeopardy by taking pyridostigmine bromide than they would have been by not taking it. This is because while the drug may protect against soman, the agent US intelligence thought Iraq had, the nerve gas the Iraqis were actually prepared to use was sarin - and pyridostigmine can make sarin more deadly to humans. ${ }^{18}$

Although the FDA and DOD defended their waiver of consent actions after the Gulf War, almost no one else did. Ultimately, Congress passed a law that repealed the FDA's military combat exception to informed consent, and put sole power to grant any future wartime exception to informed consent in the hands of the president. ${ }^{19}$ The new law provides that only the president can authorize the military to use an unapproved or investigational drug or vaccine in wartime without consent, and to do so the president must find, in writing, that obtaining consent is not feasible, is contrary to the best interests of the military, or is not in the interests of national security. ${ }^{20}$ The FDA has also adopted regulations to help the president and his advisers make this decision. ${ }^{21}$

A more basic question regarding drugs and vaccines designed for emergency use in events like biowarfare and bioterrorism remains, however: Assuming that it is impossible to ethically test the efficacy

${ }^{15}$ Annas, supra note 10, at 250 . The use of other drugs during the first Gulf War was apparently justified on this basis.

${ }^{16}$ Supra note 14.

${ }^{17}$ C.E. Wilson, Memorandum for the Secretary of tHe ARMY, SECRETARY OF THE NAVY, SECRETARY OF THE AIR ForCE (Feb. 26, 1953), reprinted in The NAZI Doctors and the Nuremberg Code: Human Rights in Human Experimentation, 343-45 (George J. Annas \& Michael A. Grodin eds., Oxford Univ. Press, 1992).

${ }^{18}$ Robert W. Haley \& Thomas L. Kurt, Self-reported Exposure to Neurotoxic Chemical Combinations in the Gulf War, 277 JAMA 231, 232 (1997); I Koplovitz et al., Reduction by Pyridostigmine Pretreatment of the Efficacy of Atropine and 2-PAM Treatment of Sarin and $V X$ Poisoning in Rodents, 18 FUNDAMENTAL \& APPLIED TOXICOLOGY 102, 103-105 (1992).

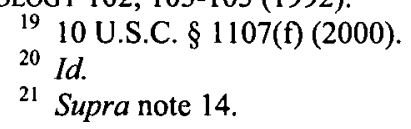


of a drug or vaccine designed for a bioterrorist or biowarfare agent (because it would be unethical to expose human volunteers to a potentially lethal agent), should there be an alternative way for the FDA to approve such agents for use in a war or other national emergency?

In 1999 the FDA proposed a set of new rules to permit the approval of such agents upon demonstration of safety in human subjects, and efficacy in appropriate multiple animal studies, and these rules were finalized in mid-2002. ${ }^{22}$ Using multiple animal models for efficacy testing seems reasonable in this context, since the FDA is right to conclude it would be unethical to expose human subjects to toxins which could be lethal to them (this would, for example, violate another provision of the Nuremberg Code). But the ethical rule requiring the informed consent of competent adults before they are subjected to drugs or vaccines that have not been demonstrated effective in human populations is equally applicable. No soldier or civilian should be required to take any such drug or vaccine (which would be offered on the basis that it could be effective) where the only scientific support for efficacy is the result of animal studies.

\section{INFORMED CONSENT TO THE ANTHRAX VACCINE}

Anthrax vaccine has been approved for use to prevent cutaneous anthrax and was mandatorily given to the troops in the Gulf War on the basis that it was an approved agent that could be given for an unapproved but closely-related use (inhalation anthrax). ${ }^{23}$ This vaccine was developed in 1970. After the Gulf War, DOD signed a sole source contract with a new company, Bioport, to produce anthrax vaccine. $^{24}$ In 1998 Secretary of Defense William Cohen ordered that all active duty troops be given the anthrax vaccine, which was to be de-

${ }^{22}$ See New Drug and Biological Drug Products; Evidence Needed to Demonstrate Efficacy of New Drugs for Use Against Lethal or Permanently Disabling Toxic Substances When Efficacy Studies in Humans Ethically Cannot Be Conducted, 64 Fed. Reg. 53,960 (proposed Oct. 5, 1999) (to be codified at 21 C.F.R. pts. 314 and 601) (seeking to approve drugs without human efficacy trials if they treat or prevent life-threatening conditions). See also New Drug and Biological Drug Products; Evidence Needed to Demonstrate Effectiveness of New Drugs When Human Efficacy Studies Are Not Ethical or Feasible; Final Rule, 67 Fed. Reg. 37,988, 37,989 (May 31,2002 ) (to be codified at 21 C.F.R. pts. 314 and 601) (finalizing the approval of marketing of drugs for life-threatening illnesses based only on animal models).

${ }^{23}$ The vaccine has been shown to protect rhesus monkeys from inhalation anthrax. See Terry C. Dixon et al., Medical Progress: Anthrax, 341 New ENG. J. MED. 815, 822 (1999).

${ }_{24}$ Thomas V. Inglesby et al., Anthrax as a Biological Weapon: Medical and Public Health Management, 281 JAMA 1735, 1740 (1999). 
livered in a series of six injections over an 18 month period. ${ }^{25}$ Some soldiers refused, and challenged the orders, arguing that the vaccine was experimental and thus could not be given without informed consent. Many of them were court-martialed. ${ }^{26}$ Anthrax vaccination was halted in 2001 when supplies ran out and the sole-source company was shut down by the FDA for failure to maintain proper manufacturing standards. ${ }^{27}$ Production and military vaccination resumed in $2002 .^{28}$ There is no evidence of any military personnel or installation ever being attacked by anthrax anywhere in the world.

The bioterrorist anthrax attacks in the U.S. were on civilians, none of whom had been vaccinated. The recommended course of treatment for exposure to anthrax is 60 days of antibiotics, and antibiotics were made available to the 10,000 people potentially exposed. ${ }^{29}$ The anthrax vaccine was not available to civilians in October or November. In late December, 2001, however, DOD agreed to supply sufficient vaccine to vaccinate the 10,000 exposed civilians. Since the anthrax vaccine was an investigational drug when used for postexposure inhalation anthrax, it could only be used in the context of a clinical trial, and then only with the informed consent of the subjects. ${ }^{30}$

The FDA and CDC designed a consent form, together with a counseling process, for use in obtaining the consent of the exposed civilians to participate in the research project. Unlike the case of the military in the Gulf War, or even the peacetime military with the anthrax vaccine, in which the government required soldiers to be vaccinated, the choice was left entirely to individuals. Government officials did not even make a recommendation as to what they thought

${ }^{25}$ Steven Lee Myers, U.S. Army Forces to be Vaccinated Against Anthrax, N.Y. Times, Dec. 16, 1997, at Al.

${ }^{26}$ Kelly Morris, U.S. Military Face Punishment for Refusing Anthrax Vaccine, 353 LANCET 130 (1999). See also Laura Johannes \& Mark Maremont, Injecting Doubt: Worries about Safety of its Anthrax Vaccine Put the Army in a Bind, WALL ST. J., Oct. 12, 2002, at Al (explaining that as of Oct. 12, 2002, 102 service men and women were court-martialed for refusing to take the vaccine).

27 Jon Cohen \& Eliot Marshall, Vaccines for Biodefense: A System in Distress, 294 SCl. 498, 500 (2001).

${ }^{28}$ Wade-Hahn Chan, What Are You Taking for That?, INSIGHT ON THE NEWS, Oct. 23, 2002, at 23.

${ }^{29}$ Altman, supra note 9.

${ }^{30}$ See Lawrence K. Altman, In Offering Anthrax Vaccines, Officials Admit to Unknowns, N.Y. TIMES, Dec. 25, 2001, at F5 (noting that "[r]ecipients must sign a five-page form that explains the experimental nature of the use and states that they should not consider the vaccine a treatment for anthrax"). BioPort's contract with the Pentagon may also permit it to sell up to $20 \%$ of its annual production to others. Judith Miller, Anthrax Vaccine Maker Calls Finances Shaky, N.Y. TIMES, Aug. 5, 2002, at Al0. 
any individual should do. D.A. Henderson, the chief bioterrorist adviser to the Secretary of Health and Human Services (HHS), justified this failure to recommend for or against taking the anthrax vaccine by saying that there was insufficient information available to make a recommendation. ${ }^{31}$ But on what basis could individuals make a decision if those with the most experience with the anthrax vaccine refused even to advise them about what action was medically reasonable?

Although no survey of the exposed civilians has been conducted, it seems likely that the potential subjects mostly decided for themselves that their 60 days (or less) of antibiotics was sufficient protection. It is also unlikely that anyone who actually read and understood the information in the consent forms provided (for adults, adolescents, and children) would have chosen to take the vaccine. Specifically, the consent forms (which are essentially identical) are five-page, singlespaced documents. Designed for a clinical trial, the forms are nonetheless captioned "Anthrax Vaccine and Drugs Availability Program for Persons Possibly Exposed to Inhaled Spores." Most of the form is in regular typeface, but the following information is in bold:

Before you decide to take part in this program, there are several important things that you should know...

- Anthrax vaccine has not been shown to prevent infection when given to people after exposure to anthrax spores...

- The vaccine that you will receive in this program has not been approved by the Food and Drug Administration (FDA) for this use and is considered investigational...

- FDA has not approved this lot of vaccine (Lot FAV063) because the company's license to produce the vaccine is under review...

- You should not consider the vaccine as a treatment for anthrax. The vaccine given in this program has not been shown to give long term protection against anthrax.

- You may have undesirable side effects from taking the vaccine.

${ }^{31}$ Id. and Sheryl Gay Stolberg \& David E. Rosenbaum, U.S. Will Offer Anthrax Shots for Thousands, N.Y. TIMES, Dec. 19, 2001, at A1. 
... DHHS is not making any recommendation whether you should or should not take this vaccine. DHHS is making the vaccine available to you to allow you to decide whether or not you wish to use the vaccine. ${ }^{32}$

The form also tells potential subjects that the vaccine is to be given in three injections, once every two weeks, and is to be supplemented by 40 days of additional antibiotics, although taking antibiotics is not required to obtain the vaccine. A two-year follow up is planned. The remainder of the form is in relatively standard language, with the exception of the phrases, "Although unconfirmed, a recent preliminary study suggests that the vaccine may be linked with an increase in the number of birth defects when given during pregnancy. At this time no one knows for sure whether this vaccine can cause fetal harm." The adolescent and pediatric forms also note that the vaccine has not been studied in anyone under the age of $18 .^{33}$

The fact that it is unethical to expose human subjects to potentially lethal toxic agents does not, of course, mean that studies cannot be undertaken with individuals who have been exposed by a terrorist and who may need an investigational drug or vaccine that has not been approved. The FDA's new regulations make provisions for such research, and appropriately so. ${ }^{34}$ Of course, informed consent must be an integral part of any such research project, even if advanced with the hope of possible therapeutic benefit. The FDA reasonably recognized this when it made the investigational anthrax vaccine available to exposed civilians only with their informed consent. ${ }^{35}$ Informed

${ }^{32} \mathrm{CDC}$, Anthrax Vaccine and Drugs Availability Program for Persons Possibly Exposed to Inhaled Spores, available at http://www.cdc.gov/od/oc/meida/adolescent.pdf; http://www.cdc.gov/od/oc/media/adult.pdf; http://www.cdc.gov/od/oc/media/parental.pdf (last visited Jan. 21, 2003).

${ }^{33}$ Id.

${ }^{34}$ See New Drug and Biological Drug Products, Evidence Needed to Demonstrate Effectiveness of New Drugs When Human Efficacy Studies Are Not Ethical or Feasible, 67 Fed. Reg. 37,988, 37,990 (May 31, 2002) (to be codified at 21 C.F.R. pts. 314 and 601) (noting that therapeutic benefits need not be established). The FDA approved pyridostigmine bromide under this rule in February 2003, just prior to the Iraq war. Donald G. McNeil, Drug Tested in Gulf War is Approved for Troops, N.Y. TIMES, Feb. 6, 2003, at A19. This approval was not without controversy. Jennifer Cohen, New Rule Triggers Debate Over Best Way to Test Drugs, 299 SCIENCE 1651 (2003).

${ }^{35}$ Shankar Vedantam \& Mary Pat Flaherty, CDC Pushed Paperwork for Anthrax Vaccinations: 48 Congressional Aides Received Inoculations, WASH. POST, Dec. 22, 2001, at A10. 
consent is not a form, nonetheless, the forms are worth reviewing for what their content reveals about the proposed study.

One of the most striking provisions is that the FDA was willing to enroll both children and pregnant women at the outset, even though the vaccine has never been used in children, and even though there is some evidence that it might be teratogenic. There is no ethical justification for putting children or fetuses at risk at this time (there is no evidence that any parent enrolled their child, or that any pregnant woman enrolled), since the 60 days of antibiotic use has always been a successful prophilaxis in humans. This seems to be another example of FDA/National Institutes of Health (NIH) policy to try to do research on children and women, without making distinctions about the type of research and the likelihood of harm to the children and women (as well as their fetuses) involved. ${ }^{36}$

The FDA does seem to have learned from its experience in the Gulf War, and did seem to understand that there could be no justification for waiving informed consent for competent adults, even in the face of a bioterrorist attack and uncertainty about the usefulness of the anthrax vaccine. Informed consent for research on competent adults is always feasible and is always ethically required. Informed consent is also required for treating competent adult civilians - only military personnel agree to accept reasonable and necessary approved medical procedures without specific consent. ${ }^{37}$ That is only one reason why it is dangerous to civilians to argue that after $9 / 11$ "we are all soldiers now."

The anthrax attacks convinced Congress and the public that the U.S. does not have sufficient safe and effective drugs and vaccines available to respond to a bioterrorist or biowarfare attack on civilians. The primary reason for the drastic increases in NIH funding, for example, are to do research in areas that might lead to better bioterrorist-

${ }^{36}$ See, e.g., Ass'n. of Am. Physicians and Surgeons v. FDA, 226 F. Supp. $2 d$ 204 (D.D.C. 2002) (containing a challenge to FDA regulation requiring drug tests on children). Almost a year later controversy erupted over a plan to test a diluted vaccinia vaccine (Dryvax) on children. Solicitation of Public Review and Comment on Research Protocol: A Multicenter Randomized Dose Response Study of the Safety, Clinical and Immune Response of Dryvax Administered to Children 2 to 5 Years of Age, 67 Fed. Reg. 66,403 (Oct. 31, 2002). The plan to test the smallpox vaccine on children was ultimately dropped.

${ }^{37}$ And it is probably time to re-examine this policy, at least in peacetime, as well. Moreover, the anthrax vaccine seems to be used currently in the military as a protection against cutaneous anthrax (which it is licensed for, but which is no real risk to soldiers) rather than as a protection against inhalation anthrax (which it is not licensed for, but which is a combat risk). 
related drugs and vaccines. ${ }^{38}$ Congress agrees with the FDA that these new agents should be approvable on the basis of animal studies of efficacy. ${ }^{39}$ There may, however, be indirect ways to test for human efficacy (such as antibody levels and tests like those used to determine the efficacy of diluted smallpox vaccine), and when such indirect human efficacy measures exist, their use should be required for FDA approval.

A related question is whether there should be a new narrower category of FDA approval for products that cannot be tested for efficacy, and whose use would be limited to certain populations in specific circumstances. Although there is no precedent for this, teratogenic drugs like accutane and thalidomide have labeling that attempts to limit their prescription to people taking effective birth control measures. $^{40}$ This is reasonable. Similarly, when drugs and vaccines are developed for the use of soldiers in war it seems reasonable to restrict their use to competent adults, and to exclude children. It also seems reasonable to limit the use of the agent to military personnel at least if combat and the military mission are the rationales used to approve the use - and to require that the product be labeled "For Military Use Only." If such a restriction is not made, there is at least the potential for the drug to be used for other reasons (since once the drug or vaccine is approved for one purpose, physicians can lawfully prescribe it for others if it is available to civilians) although the primary reason short cuts were taken in its testing was military necessity.

The labeling of bioterrorist drugs and vaccines is more complicated because the consumers are primarily civilians. A label like, "For Use Only in the Event of a National Emergency or Bioterrorist Attack," might not be sufficient, although that will be the primary reason the drug or vaccine has been approved without the usual re-

${ }^{38}$ NIH Breaks Down How It Will Spend Bioterrorism Funds, WALL ST. J., Feb. 19, 2002, at A4.

${ }^{39}$ Congress required the FDA to adopt the regulation cited in note 22 by legislation; see Public Health Security and Bioterrorism Preparedness Response Act of 2002, H.R. $3448,107^{\text {th }}$ Cong. $\$ \S 122-23$ (2002); Bioterrorism Preparedness Act of 2001 , S. $1765,107^{\text {th }}$ Cong. $\$ \S 405-06$ (2001); both of which contained this language which became law in 2002.

${ }^{40}$ See, e.g., George J. Annas \& Sherman Elias, Thalidomide and the Titanic: Reconstructing the Technology Tragedies of the Twentieth Century, 89 AM. J. PuB. HEALTH 98 (1999) (describing the FDA's most stringent postmarking monitoring ever used for reintroduction of thalidomide, which caused serious birth defects in the 1950 s and $1960 \mathrm{~s}$ ).

41 During the Gulf War pyridostigmine bromide (as a pretreatment for a poison gas attack) was labeled "For military use and evaluation" instead of the usual IND label, "Caution: New Drug-Limited by Federal Law to Investigational Use." It was approved for use by the troops just prior to the Iraq war. See supra note 34. 
quired human efficacy studies. To permit it to be used by physicians for other purposes is not justified.

In reality, however, it is probably not the labeling as much as the physical control of these new drugs and vaccines that will matter. For example, if the products are all manufactured under military or HHS contract, and the entire supply is controlled either by DOD or HHS, their availability and use will be governed by these agencies, and the drugs and vaccines will not be available to private physicians or the general public (except in times of national emergency) in any event. This, for example, is the current situation with the anthrax vaccine that is wholly supplied by a single manufacturer who is under contract only to manufacture it for DOD. That is why only DOD can authorize its supply to others, as it did in December, $2001 .^{42}$ Anthrax research continues on a number of fronts: can fewer than six shots of the current vaccine provide immunity?, can a test for antibodies in the blood measure immunity?, what side effects have been experienced by the military personnel who have taken the vaccine?, and, of course, can a better vaccine be developed to replace the current one that is "old, inefficient and the cause of many complaints.",43

There is a tendency to jettison fundamental rules that protect citizens against arbitrary government action, especially those like informed consent, in times of war or crises like bioterrorism. Reflection has caused us to regret our haste in waiving informed consent in the Gulf War and this mistake was not repeated during the Iraq War. Not only was informed consent feasible with the troops, but the use of pyridostigmine bromide as a pretreatment to a soman attack is contraindicated for the primary chemical agent the Iraqis actually had in their arsenal, sarin. When confronted with this fact by U.S. Senator Jay Rockefeller in a Senate hearing in 1997 General Norman Schwarzkopf admitted that the military was responding primarily out of fear rather than knowledge, saying: “. . . we were scared to death of the Iraqi chemical weapons ... what you are probably recounting, is a reaction, perhaps an overreaction to coming up with any kind of antidote that they could come up with to prevent our troops from being killed by chemical weapons., ${ }^{, 44}$ At a later 1997 hearing before the same panel, General Colin Powell testified that he approved the drugs and vaccines used "with the full assurance from the FDA that they

42 But see Judith Miller, supra note 30.

${ }^{43}$ Eliot Marshall, Anthrax Vaccine Begins a New Round of Tests, 295 SCIENCE 427, 427 (2002).

${ }^{44}$ Persian Gulf War Illnesses, Part II: Hearing Before the Comm. on Veterans' Affairs United States Senate, $105^{\text {th }}$ Cong. 26 (1997) (testimony of General Norman H. Schwarzkopf, U.S. Army Retired). 
were safe for human use and that they were effective." 45 In other words, the federal agencies were wrongly relying on the expertise of each other rather than exercising their own independent judgment: FDA granted DOD's request for a combat waiver of consent because it believed that its use was a military decision for DOD to make, and DOD used the drugs and vaccines it did because it thought a drug safety decision had been made by the FDA.

There is no reason for civilians (or soldiers) to have to trade safety for liberty in an emergency in which unapproved or partially-tested drugs or vaccines are made available. The choice to use them should continue to be an individual's choice, as it properly was for civilians in the case of the anthrax vaccine. The public health or military authorities that make these drugs and vaccines available, however, should only do so if they are prepared to recommend their use. Otherwise the decision to make them available becomes purely a political one, made to cover the behinds of government officials, not a medical or public health one. ${ }^{46}$

\section{THE "MODEL" STATE EMERGENCY HEALTH POWERS ACT}

In the immediate aftermath of $9 / 11$ and the subsequent anthrax attacks, hospitals, cities, states, and federal officials began developing or revisiting plans for future biological attacks. The federal response almost immediately emphasized stockpiling drugs and vaccines that could be used to respond to a future attack, especially one involving smallpox. $^{47}$ Other initiatives have proposed enhancing the public health infrastructure of the country (especially its ability to monitor emergency department diagnoses and pharmacy sales of relevant drugs), and the training of first responders to recognize and treat the diseases most likely to be caused by a bioterrorist attack (such as anthrax, smallpox, and plague). Major efforts are also underway to im-

45 Persian Gulf War Illnesses, Part III: Hearing Before the Comm. on Veterans' Affairs United States Senate, $105^{\text {th }}$ Cong. 14 (1997) (testimony of General Colin Powell, Former Chairman of the Joint Chiefs of Staff).

46 In this regard there are many lessons to be learned from the 1976 attempt to vaccinate all Americans against swine flu. See, e.g., RICHARD E. NEUSTADT \& Harvey V. Fineberg, The SWIne Flu AfFair: Decision-Making on a SlipPery Disease (U.S. Dept. HEW, 1978). See also Gina Kolata, Flu: The Story of THE GREAT INFLUENZA PANDEMIC OF 1918 AND THE SEARCH FOR THE ViRUS THAT CAUSED IT 129-95 (1999).

${ }^{47}$ See William Broad, U.S. Acts to Make Vaccines and Drugs Against Smallpox, N.Y. TIMES, Oct. 9, 2001, at F1 (discussing U.S. response to the threat of smallpox). 
prove coordination and communication among local, state, and federal officials responsible for emergencies, and to more clearly delineate lines of authority involving "homeland security." All of these are reasonable and responsible steps our government should take.

On the other hand, planning for mass quarantine and forced vaccination - likely with investigational vaccines - are unreasonable steps that are more likely to foster public panic and distrust than to be effective in a real emergency. Mass quarantine was a staple of public health from the $14^{\text {th }}$ century to the early $20^{\text {th }}$ century, and its implementation has been historically justified by labeling those groups quarantined as not only dangerous but almost diabolical. ${ }^{48}$ As historian-physician Howard Markel has put it:

History teaches us that society has no shortage of means available to dehumanize and minimize so-called undesirable groups of people. The grave risks of this minimization process are magnified when combined with the threat of contagious disease. It is at this moment that rhetorical scapegoating may be transformed into a mentality of quarantine. Not only does the infectious disease become the 'enemy' but, so, do the human beings (and their contacts) who have encountered the microbe in question. A common symptom of the quarantine mentality is to do everything possible to prevent the spread of an epidemic, often at the neglect of the human or medical needs of those labeled contagious. ${ }^{49}$

Properly worried that many state public health laws are outdated and perhaps inadequate to permit state officials from effectively containing an epidemic caused by a bioterrorist attack, in the wake of 9/11 the CDC advised all states to review the adequacies of their laws with special attention to quarantining people in the event of a smallpox attack. ${ }^{50}$ In addition, the CDC released a proposed model law for the states, entitled the "Model State Emergency Health Powers

${ }^{48}$ HoWARD MaRKEL, QUARANTINE!: EAST EUROPEAN JEWISH IMMIGRANTS AND THE NEW YORK CITY EPIDEMICS OF 1892 185-86 (1997).

${ }^{49}$ Id.

${ }^{50}$ See CDC Smallpox Response Plan and Guidelines, available at http://www.bt.cdc.gov/agent/smallpox/response-plan/index.asp (laying out state and local guidelines for vaccination). See also Justin Gillis \& Ceci Connolly, U.S. Details Response to Smallpox: Cities Could be Quarantined and Public Events Banned, WASH. PosT, Nov. 27, 2001, at Al (suggesting increased awareness by public officials in detecting smallpox outbreak and a possibility of quarantine should control measures fail). 
Act"(model act) on October 23, 2001. ${ }^{51}$ The act was written under extreme time pressure and in the state of high emotion. Co-drafter

${ }^{51}$ This model was released on October 23, 2001 to great fanfare, but has since been removed from the sponsor's website. A copy is on file with the author. I first saw the model act on October 31 when it was emailed to me by project director James G. Hodge, Jr. On November 1, I emailed him and the distribution list the following response:

Dear Mr. Hodge: Thanks for bringing your draft model law to my attention. There certainly is a need to improve our public health infrastructure and to find new and effective drugs and vaccines to deal with the threat of bioterrorism. I think uniform state laws can be a useful tool for state legislatures and that some good could come out of this exercise. I do not however think your current proposal is helpful, since it treats both American citizens and American physicians and hospitals as the enemy, and grants unnamed and unaccountable "public health officials" unprecedented (and I think unconstitutional) power to compel both citizens and their physicians to undergo testing and treatment and perhaps quarantine with no standards as to how these powers are to be applied or reviewed. This is, of course, the old Soviet model of public health (lots of power and no standards for applying it), hardly a "new" American model. The problem RIGHT NOW is not the lack of public health power, but a lack of public health honesty (about how little is known about anthrax, for example) and the lack of vaccines and drugs to deal with various risks. It is NOT the case that Americans are resisting being tested or treated (what makes you think this is the problem?); rather it is the CDC and other public health officials who are urging Americans who are lining up to be screened for anthrax in New York City, for example, to go home and not worry about it, and people who want to begin antibiotic treatment immediately not to do so. Also, I have not witnessed any physicians or hospitals around the country that have failed to offer full voluntary cooperation with public health and even law enforcement officials.

In short, this seems to be an overreaction to a crisis that significantly misses the mark. I urge you not to stick to an unrealistic November 7 rewrite deadline, but to take the time to do a more thoughtful job on this. Such a rewrite would require, among other things, much more careful attention to definitions (including limiting mandatory actions to communicable diseases), taking the constitutional rights of American more seriously (and not trying to rely so heavily on Jacobson, a case that is almost 100 years old and that reflects both old public health practice and outdated constitutional law), treat Americans as the beneficiaries and friends of public health, not as your enemies; treat private physicians and hospitals as allies, not enemies; and develop explicit and understandable standards under which power over individuals and private institutions can be exercised; and eliminate the immunity provisions.

I hope these comments are helpful, and would be happy to discuss any or all of them with you. Sincerely, George J. Annas (copy of email on file with the author; there was no response from the authors of the Model Act).

Shortly thereafter, on Nov. 7, 2001, Janlori Goldman and Joanne L. Hustead of Georgetown University's Institute for Health Care Research and Policy, wrote Larry Gostin a much longer letter, saying among other things: 
Steve Teret, for example, explained that he had just finished reading José Saramago's Blindness when asked to help on this project. He

Given the current political climate and the intense desire of policymakers and the public to be fully prepared for similar attacks and acts of bioterrorism, we believe it is critical for proponents of any proposed model legislation to be especially vigilant in protecting civil liberties and privacy rights. As an initial matter, we are extremely concerned with the breathtakingly expansive scope of the definition of "public health emergency" - a definition that is central to the invocation of the extraordinary powers granted to state authorities. Most alarming is the inclusion of "epidemic" and "pandemic" in this definition (terms which themselves are not defined). We approached this model with the understanding that it was intended to combat new, emerging threats, specifically the outbreak of disease caused by bioterrorism, but the model act, as drafted, appears to allow the existence of any epidemic, whatever the cause, to trigger the emergency powers vested in state authorities - powers that include the ability to quarantine individuals and compel treatment...

We do not argue that quarantine, isolation, or forced treatment - with the obvious attendant loss of liberty and autonomy - are never an appropriate exercise of government power. There may be circumstances where such action is the only and last resort. We do question, however, the breadth of situations in which state authorities would have these powers under the model act, and we urge you to more precisely define and limit the circumstances under which such extraordinary powers could be invoked...

We have several concerns about the draft's approach to protecting the privacy of medical information.

The draft does not consistently restrict access to protected health information (PHI) to those within the public health authority (or the public safety authority) with a need to know, or put explicit limits on disclosure of such PHI by state authorities. Several sections, notably section 201 (which creates a mandatory reporting system), section 202 (which requires public health authorities to identify, interview, and counsel exposed individuals and track other potentially exposed individuals), and section 203 (which requires public health and public safety authorities to share information about reportable illnesses) will result in the accumulation of PHI by public health and safety authorities. We believe it is essential for this model law to state explicitly that all PHI collected or received by state public health or public safety authorities will be available only to those within the authorities with a need to know. (Section 2043(c)'s reference to exchanges between "authorized personnel" is a start.) It also is essential for this model law to prohibit disclosures of PHI by state authorities, with stated exceptions that are limited to the reasons why the information was collected in the first place. (letter on file with the author)

In retrospect such comments were inevitable. As two sympathetic commentators put it, "In their understandable haste, the Georgetown-Hopkins drafting group also produced a confusing document, posted first and discussed afterwards." John M. Colmers \& Daniel M. Fox, The Politics of Emergency Health Powers and the Isolation of Public Health, 93 AM. J. PuB. Health 397, 398 (2003). And see generally, Ronald Bayer \& James Colgrove, Rights and Dangers: Bioterrorism and the Ideologies of Public Health, in IN THE WAKE OF TERROR 51-74 (Jonathan D. Moreno ed., 2003). 
told an interviewer that the horrific quarantine described in this fictional epidemic of blindness was something he could not get out of his mind. In his words, "It was the most disturbing book I've ever read." 52

The draft act permits the Governor to declare a public health emergency, after which the state's public health officials are given extraordinary power to essentially take over all of the health care facilities in the state, order physicians to act in certain ways, and order citizens to submit to examinations and treatment on the threat of being quarantined or criminally punished for refusing. Under the act, public health officials, and those working under their authority, are immune from liability for their actions (except for gross negligence and willful misconduct), including those which cause permanent injury or death. Specifically, the act defines a public health emergency (the condition that permits the Governor to declare a state of public health emergency), as "an occurrence or imminent threat of an illness or health condition, caused by bioterrorism, epidemic or pandemic disease, or novel and highly fatal infections agent or biological toxin, that poses a substantial risk of a significant number of human fatalities or incidents of permanent or long-term disability."

An emergency declaration permits the Governor to suspend state regulations, transfer personnel, and mobilize the militia. All public health personnel will be issued special identification badges, which they shall wear "in plain view" that "shall indicate the authority of the bearer to exercise public health functions and emergency powers ..." In regard to health care facilities, public health personnel may "compel a health care facility to provide services or the use of its facility if such services or use are reasonable and necessary for emergency response ... includ[ing] transferring the management and supervision of the health care facility to the public health authority . . .,"54

Public health personnel are given exceptionally broad powers, and failure of physicians and citizens to follow their orders is a crime:

Sec. 502(a)(4) Individual examination or testing. Any person refusing to submit to the medical examination and/or testing is liable for a misdemeanor. If the public health authority

52 Susan Muaddi Darraj, Model Legislation: Balancing Civil Rights and Public Policy, Johns HopkIns PUB. Health MaG., Late Fall 2001, at 18. In the same article Gostin is quoted as saying that the model act is "polished and strong because we had a brain trust of the best public health minds at Hopkins and the best legal minds at Georgetown, thus ensuring the best dividends for our nation." Id.

${ }_{53}$ Model Act, Sec. 104(f) at p. 11, supra note 51.

${ }^{54}$ Id., sec. 402(b), at 20, supra note 51. 
is uncertain whether a person who refuses to undergo medical examination and/or testing may have been exposed to an infectious disease or otherwise poses a danger to public health, the public health authority may subject the individual to isolation or quarantine.

Sec. 502(b) Health care provider assistance. To require any physician or other health care provider to perform the medical examination and/or testing. Any person refusing to perform a medical examination or test as authorized herein shall be liable for a misdemeanor ... An order of the public health authority given to effectuate the purposes of this subsection shall be immediately enforceable by any peace officer.

Sec. 504(b) Vaccination and treatment. Individuals refusing to be vaccinated or treated shall be liable for a misdemeanor. If, by reason of refusal of vaccination or treatment, the person poses a danger to the public health, he or she may be subject to isolation or quarantine ... (c) An order of the public health authority ... shall be immediately enforceable by any peace officer. ${ }^{55}$

Of course, state public health, police, fire, and emergency planners should be clear about their authority, and to the extent the model act encourages states to review their emergency laws this is constructive. On the other hand, many of the provisions of this model act, especially those giving authority of public health officials over physicians and hospitals, and authority to quarantine without meaningful standards, seem to be based on the assumption that neither physicians nor the public are likely to cooperate with public health officials in the aftermath of a bioterrorist attack, and that panic is likely. This assumption itself seems to be based on the results of tabletop exercises involving simulated bioterrorist attacks, including TOPOFF and Dark Winter. TOPOFF involved a simulated bioterrorist attack on Denver by using aerosolized Yersinia pestis, the bacteria that causes plague. ${ }^{56}$

${ }^{55} I d$. at $25-29$.

${ }^{56}$ TopOff (Top Officials) was a Congressionally mandated exercise to simulate three simultaneous attacks: chemical in New Hampshire, nuclear in Washington, D.C., and biological in Denver. The most dramatic was the scenario involving the aerosol release of pneumonic plague at the Denver Performing Arts Center and the four-day sequel played out in May 2000 which included the closing of Colorado's borders on day three. Among the questions raised by Denver TopOff were: who is in charge, how to handle drug supply, how to avoid a hospital crisis, whether and how to quarantine those infected, and whether to close city and state borders to contain the disease. Blohazard News, TOPOFF: A Plague EXERCise, at http://www.biohazardnews.net/scen_plague.htm (May 2000). 
Dark Winter was a tabletop exercise that simulated a smallpox attack on Oklahoma City. ${ }^{57}$ Using these simulated cases as a basis for legislation, however, is unreasonable given the overwhelming voluntary cooperation of the public, physicians, and hospitals to both $9 / 11$ and the anthrax attacks.

Selective blindness was perhaps inevitable, and led to three major objections to the initial version of the model act. First, it is far too broad, applying as it does not just to a smallpox attack, but to nonemergency conditions as diverse as our annual flu epidemic and the HIV epidemic. ${ }^{58}$ Second, although it may make sense to put public health officials in charge of responding to a smallpox attack, it may

${ }^{57}$ Dark Winter, played out June 22 and 23, 2001, was a simulated smallpox attack on Oklahoma City. The exercise resulted in five major "learning points," including that biological weapons could threaten vital national security interests, current organizational structures are not well suited to managing a biological attack, there is no surge capacity in our health system, dealing with the media is critical, and finally, "Should a contagious bioweapon pathogen be used, containing the spread of disease will present significant ethical, political, cultural, operational and legal challenges. THE ANSER INSTITUTE FOR HOMELAND SECURITY, DARK WINTER, $a t$ http://www.homelandsecurity.org/darkwinter/index.cfm (last visited Jan. 19, 2003).

${ }^{58}$ See Wendy Parmet \& Wendy K. Mariner, A Health Act that Jeopardizes Public Health, Boston GloBe, Dec. 1, 2001, at A15 (noting that the definition of "emergency" in the Model Act is too broad and without review). See also letter of the New England Coalition for Law \& Public Health to Secretary Tommy Thompson, dated Nov. 13, 2001 which reads in part:

It is especially important today that public health retain the trust of the American public. The Model Act risks jeopardizing the public's confidence in both state and federal public health agencies by viewing public health as an arm of law enforcement rather than as an independent health protection profession. The Act treats the American public, rather than a chemical, biologic, disease (or even terrorist) as the source of the problem. It relies on coercion to the exclusion of identifying and reducing risks, distributing medicines, and educating the public about prevention and treatment. This approach will neither protect the public health nor support the efforts of public health officials. To sustain public support for public health measures, both now and in the long run, public health officials must be viewed as acting in the interest of the population. This cannot happen if they are seen as seeking extreme, unnecessary powers that can be used arbitrarily, against individuals who have committed no crime but becoming ill.

We firmly believe that there is no need for model legislation enhancing public health's emergency powers. If there is any value in changing some state laws affecting public health, it lies in placing constitutional limits on the use of emergency powers to make the text of old statutes consistent with modern practices and amending statutes to provide and facilitate true commitments to public health ... Signed by George J. Annas, Leonard H. Glantz, Wendy K. Mariner, Frances H. Miller, Patricia A. Roche, Richard A. Daynard, Wendy E. Parmet, Anthony Robbins, Eileen O'Neil, and Nicholas A. Ashford (on file with author). 
not make sense to put them in charge of responding to every type of a bioterrorism event. This is because although the state public health department has a major role to play in limiting the public's exposure to a bioterrorist agent, contact identification, information gathering and dissemination, most of the actual treatment of affected individuals and preventive actions at the level of identifiable patients will be done by physicians, nurses, emergency medical personnel, and hospitals. ${ }^{59}$ The primary role of public health authorities will usually be, as it was after the anthrax attacks, to provide guidance to the public and other government officials about how to identify and deal with the disease, and to provide laboratory facilities to assess exposure and definitively establish diagnoses.

The third objection to the act is that there is no evidence from either $9 / 11$ or the anthrax attacks that physicians, nurses, or members of the public panic, are reluctant to cooperate in responding to a bioterrorist attack, or are reluctant to take drugs or vaccines recommended by public health or medical officials. Quite the opposite, physicians and hospitals in the areas affected, universally volunteered their time, space, and expertise to respond to $9 / 11$, and the public lined up to be tested for anthrax and stockpiled ciprofloxacin. Instead of resisting treatment or testing, the public actually wanted treatment and testing so much that the CDC had to publicly recommend against both. ${ }^{60}$ The major problem in a bioterror attack or epidemic will be delivering drugs to a public that is demanding them, not forcing treatment. Another important lesson learned from $9 / 11$ was that Americans are primarily concerned about the safety of their families - and it will not be possible to separate them from their families if they do not believe separation is in their family's best interests.

59 See Donald A. Henderson, Public Health Preparedness, in SCIENCE AND TECHNOLOGY IN A VULNERABle WORLD: SUPPLEMENT TO AAAS SCIENCE AND TECHNOLOGY POLICY YEARBOOK 200337 (Albert H. Teich et al. eds., 2002), available at http://www.aaas.org/spp/yearbook/2003/yrbk03.htm (expressing need to prepare physicians at local level to respond to bioterrorism). And as bioterrorist expert Margaret Hamberg has noted, "A strong and robust public health system requires effective working partnerships with the medical care community." Margaret A. Hamburg Addressing Bioterrorist Threats: Where Do We Go from Here? 5 EMERGING INFECTIOUS DISEASES 564, 564 (1999).

${ }^{60}$ Jonathan Bor, Americans are Taking Antibiotics into own Hands, in Case of Anthrax: Officials Vainly Caution Against Stockpiling, Random Self-medication, BALT. SUN, Oct. 13, 2001, at 5A; see also Postal Service Security: Hearing on Postal Service Security Before the Senate Comm. on Government Affairs, $106^{\text {th }}$ Cong. (Oct. 31,2001 ) (providing testimony of Tara O'Toole, Deputy Director of Center for Civilian Biodefense). 
Of course anthrax is not spread from person-to-person like smallpox. The response could have been different in a Dark Winter-type smallpox attack, or if thousands or tens of thousands of people had become infected with anthrax. Nonetheless, there is no empirical evidence to suggest that a draconian state criminal quarantine law of the type authorized in the act is necessary or desirable. Individuals with smallpox, for example, are most infectious only after they develop fever and a rash; and then they are usually so sick and immobile that they will likely accept whatever care is available. ${ }^{61}$ Moreover, the "long incubation period (10-17 days before a rash develops) almost ensures that some persons who are infected in the [smallpox] attack will have traveled great distances from the site of exposure before the disease is recognized or quarantine could be implemented."62 The key to an effective public health response is making voluntary treatment available. Without a sufficient supply of smallpox vaccine, for example, even police-supported quarantine would not likely be effective. People will come to centers for treatment; they will obviously flee if they do not want treatment and all that is offered is confinement and separation from their families.

Finally, even if it is concluded that a quarantine law might be useful to respond to a bioterrorist-induced emergency (e.g., by permitting the few unwilling Americans, if there are any, to be treated, vaccinated, or quarantined), such a law should be a federal law, not a state law. This is because bioterrorism is a matter of national security, not just state police powers. Existing federal quarantine law based on the commerce clause (and which has special provisions for tuberculosis, cholera, plague, smallpox, viral hemorrhagic fever and yellow fever) could usefully be examined and updated to deal with bioterrorism. ${ }^{63}$ Moreover, to the extent that the federal government funds "dual use" public health infrastructure, federal public health officials will be able to dictate its use. The Governors of the states involved in actual anthrax attacks all realized that bioterrorism is fundamentally a federal

${ }^{61}$ E.g., Donald A. Henderson et al., Smallpox as a Biological Weapon: Medical and Public Health Management, 281 JAMA 2127, 2129 (1999).

${ }_{62}$ Joseph Barbera et al., Large-Scale Quarantine Following Biological Terrorism in the United States: Scientific Examination, Logistic and Legal Limits, and Possible Consequences, 286 JAMA 2711, 2714 (2001).

63 See Public Health Service, 42 U.S.C. $\$ 264$ (2001) (noting use of authority by the Surgeon General to control communicable disease outbreak); Quarantine, inspection, licensing: interstate quarantine, 42 C.F.R. 70 (2000). Of course bioterrorism is fundamentally a global issue as well. See Wendy Mariner, The Wrong $R e$ sponse, NAT'L L.J., Dec. 17, 2001, at A20, and David F. Fidler, Bioterrorism, Public Health, and International Law, 3 CHI. J. INT'L L. 7 (2002). 
issue, and quickly called for action by both the FBI and the CDC to deal with the attacks. ${ }^{64}$

\section{CIVIL LIBERTIES AND PUBLIC HEALTH EMERGENCIES}

The act is premised on a not uncommon belief that in public health emergencies there must be a tradeoff between protecting civil rights and effective public health interventions. ${ }^{65}$ There is, of course, precedent for this belief, and the preamble to the model act cites the 1905 case of Jacobson v. Massachusetts for the proposition that "the whole people covenants with each citizen, and each citizen with the whole people, that all shall be governed by certain laws for the 'common good." ${ }^{\prime 66}$ Jacobson involved a Massachusetts statute that permitted local boards of health to require vaccinations when they deemed it "necessary for the public health or safety." There were no quarantine provisions in that law, and refusal was punishable by a $\$ 5$ fine. Vaccination refusals at the beginning of the last century - before the Flexner report - were anticipated because vaccination itself remained controversial, there were no antibiotics, physicians were not universally trusted, science and medicine was in its infancy, and hospitals were seen primarily as "pest houses." 67 Trade offs between civil liberties (the right to refuse treatment) and public health (mandatory vaccinations) seemed necessary in such circumstances. There was no FDA, no such thing as an investigational drug or vaccine, and the doctrine of informed consent wouldn't be articulated for more than half a century.

The U.S. Supreme Court cited the military draft as precedent for upholding the Massachusetts law. ${ }^{68}$ The point is not that the constitu-

${ }^{64}$ See, e.g., Eric Lipton, On a Day of Jitters, City and F.B.I. Differ Over Anthrax Sweep at $A B C$, N.Y. TIMES, Oct. 17, 2001, at B6 (discussing the combination of local police and federal agents during the anthrax outbreak at $A B C$ ).

${ }^{65}$ James G. Hodge, Jr., Bioterrorism Law and Policy: Critical Choice's for Public Health, 30 J. L. MED. \& ETHICs 254 (2002). The drafters knew quarantine and restricting civil liberties would be controversial. As James Hodge put it in November, 2001, "They [vaccination and quarantine] are the central issues of this act, and they will probably be the most controversial." Quoted by Deidre Davidson, Health Center's Quarantine Proposal Sparks Debate, Boston Law Tribune, Nov. 12, 2001 at 1, 2. More recently Hodge has said: "These are not going to be popular measures, but necessary ones." Quoted by Marcia Coyle, Bioterror Law Gains Ground, NAT'L L.J., Sept., 23, 2001, A1, A8, available at http://www.nlj.com/archive/0923.shtml.

66 Jacobson v. Massachusetts, 197 U.S. 11, 27 (1905).

${ }^{67}$ Charles Rosenberg, The Care of Strangers: The Rise of America's HOSPITAL SYSTEM 15-32, 209-11 (1987).

${ }_{68}$ Jacobson, supra note 66, at 29. 
tion does not give the government wide latitude to respond in times of war and public health emergencies - it does; the point is that civil rights tradeoffs are not always required for effective public health response. Just as we have been able to abolish the draft and go to an all volunteer armed forces, so it seems reasonable to think that we can predictably rely on well-informed Americans - who are not the enemy in a bioterrorist attack - to follow the reasonable instructions of government officials they trust for their own protection.

Almost one hundred years after Jacobson, neither medicine nor constitutional law is what it was. We now take constitutional rights much more seriously, including the constitutional right of a competent adult to refuse any medical treatment, even lifesaving treatment. ${ }^{69}$ Of course, we still would permit public health officials to quarantine individuals who have a serious communicable disease who either cannot or will not accept treatment for it or agree to stay in their home, and who threaten to infect others with it, such as active tuberculosis. Even then, however, we require public officials to use the "least restrictive alternative" and resort to quarantine only after other interventions, such as directly observed therapy, have failed. ${ }^{70}$ Involuntary confinement almost always represents a failure of modern public health. It also must be accompanied by procedural due process protections, including the right to legal representation and to a judicial hearing. ${ }^{71}$

The act seems to have been drafted for a different age, and would be more at home in the U.S. of the $19^{\text {th }}$ century rather than the $21^{\text {st }}$. Today, all adults have the constitutional right to refuse examination and treatment, and such a refusal should not result in involuntary confinement simply on the simple say so of a public health official. At the very least, the individual with a contagious disease should have

${ }^{69}$ See George J. Annas, The Bell Tolls for a Constitutional Right to Physician-Assisted Suicide, 337 NEw ENG. J. MED. 1098 (1997) (discussing Washington v. Glucksberg, 521 U.S. 702 (1997) and Vacco v. Quill, 521 U.S. 793 (1997)). See also Sell v. U.S., 2003 U.S. LEXIS 4594 (June 16, 2003) (prisoner awaiting trial may not be medicated against his will to make him competent to stand trial without a judicial hearing and a finding that the medication is both necessary to further essential governmental interests and is in the patient's best medical interest in light of his medical condition).

${ }^{70}$ See, e.g., Greene v. Edwards, 263 S.E.2d 661, 663 (W.Va. 1980) (stating specific procedural safeguards that must be followed before committing individuals for tuberculosis treatment); City of Newark v. J.S., 652 A.2d 265, 272 (N.J. Super. L. 1993); George J. Annas, Control of Tuberculosis: The Law and the Public's Health, 328 NEW ENG. J. MED. 585 (1993). The analogy modern courts have adopted is to the due process protection now constitutionally-required to confine a person to an institution because they are mentally ill and dangerous.

71 Id. See generally, Wendy Parmet, AIDS and Quarantine: The Revival of an Archaic Doctrine, 14 HofSTRA L. REV. 53 (1985). 
the option of identifying a qualified examining physician of their own, and if isolation is necessary, isolating him or herself in their own home. Requiring physicians to treat patients against their will and against their medical judgment under penalty of criminal law has no precedent at all, makes no ethical or legal sense, and can only produce destructive conflict. Governors already have broad emergency powers; there is no compelling reason to expand them. ${ }^{72}$

Constitutional rights need not be compromised for effective public health intervention. But even if policy makers were unconcerned with restricting civil liberties, such a strategy as that outlined in the model act would be counterproductive. This is because the proposal is likely to undermine public trust in public health, trust that is absolutely essential to containing panic in a bioterrorist-induced epidemic. Unlike 1900, for example, we now have 24 hour a day news television, the internet, cell phones, and automobiles. These make effective large-scale quarantine impossible unless the public is convinced that it is absolutely necessary to prevent the spread of fatal disease and is fairly and safely administered. Making it a crime to disobey a public health officer, for example, will only increase public distrust in that it proclaims that public officials cannot provide valid reasons for their actions. Former Senator Sam Nunn, who played the president in the Dark Winter exercise, accurately observed after it was over: "There is no force on earth strong enough to get 250 million Americans to do something they do not believe is in their own best interests or that of their families." $" 73$

The necessity for maintaining public trust and confidence also means that the argument that in a public health emergency there must be a tradeoff between effective public health and protecting civil rights is simply wrong. As the AIDS epidemic has demonstrated, the promotion of human rights can be essential to deal effectively with an epidemic. Public health officials recognized early that draconian mandatory HIV screening measures, for example, would simply help drive the epidemic underground where it would spread faster and wider. ${ }^{74}$ Likewise, draconian quarantine measures seem most likely to create public panic that will encourage people to avoid public health officials and physicians rather than seek them out. In this regard, pro-

${ }^{72}$ See supra note 58.

${ }^{73}$ Quoted by Tara O'Toole, oral presentation, Boston University School of Public Health, October 18, 2002.

${ }_{74}$ See, e.g., Lawrence Gostin \& Jonathan Mann, Toward the Development of a Human Rights Impact Assessment for Formulation and Evaluation of Public Health Policies, in HeAlTH AND HUMAN RIGHTS: A READER 54 (Jonathan Mann et al., eds., 1999). 
tection of civil liberties is a core ingredient to successfully responding to a bioterrorist attack. Treating our fellow citizens as the enemy, and using police tactics or martial law to force treatment and isolate them, is much more likely to cost lives than to save them. This is one reason why there has not been a large-scale quarantine in the U.S. since World War I, and why bioterrorism experts doubt that a mass quarantine could be effective. ${ }^{75}$

\section{THE REVISED MODEL ACT}

On December 21, 2001, in response to criticisms of the model act, including those I have summarized, a revised version was released. No one any longer considers the act a "model." Instead, the December version is labeled simply a "draft for discussion." The December version does "not represent the official policy, endorsement, or views" of anyone, including the authors themselves and the $\mathrm{CDC} .^{76}$ As then

75 See Barbera, supra note 62, at 2713-14 (noting that quarantines that were undertaken in the past century primarily involved recent immigrants and ethnic minorities).

${ }_{76}$ See The Center for Law and the Public's Health at Georgetown and Johns Hopkins Universities, The Model State Emergency Health Powers Act, Draft (Dec. 21, 2001) [hereinafter MSEHPA Draft] at http://www.publichealthlaws.net/MSEHPA/MSEHPA2.pdf.

A comparison of the cover pages of the two versions of "The Model State Emergency Health Powers Act" is both instructive and deeply disturbing. The October 23, 2001 version contains the following language immediately under the act's title and the date: "Prepared by The Center for Law and the Public's Health at Georgetown and Johns Hopkins Universities For the Centers for Disease Control and Prevention In collaboration with the: $\mathrm{Na}$ tional Governors Association, National Conference of State Legislatures, Association of State and Territorial Health Officials, National Association of City and County Health Officers, and National Association of Attorneys General."

The cover page of the December 21, 2001 version (apparently the final one) reads as follows after the title of the Act: "The Model State Emergency health Powers Act: As of December 21, 2001. A Draft for Discussion Prepared by: The Center for Law and the Public's Health at Georgetown and Johns Hopkins Universities For the Centers for Disease Control and Prevention [CDC] To Assist: National Governors Association [NGA], National Conference of State Legislatures [NCSL], Association of State and Territorial Health Officials [ASTHO], and National Association of County and City Health Officials [NACCHO].

The cover page also contains a footnote to the title of the Act which reads: "Members of the National Association of Attorneys General (NAAG) also provided input and suggestions to the drafters of the Model Act. The language and content of this draft Model State Emergency Health Powers Act do not represent the official policy, endorsement, or views of the Center for Law and the Public's Health, the CDC, NGA, NCSL, ASTHO, NACCHO, 
Director of the CDC, Jeffrey Koplan, wrote me on December 28, 2001: "The draft model act does not represent any official or unofficial CDC position." 77

Although the revised act is a modest improvement (some suggestions were taken by the authors), all the fundamental problems remain. Failure to comply with the orders of public health officials for examination or treatment is no longer a crime but results in isolation or quarantine. Criminal penalties continue to apply for failure to follow isolation or quarantine "rules" that will be written at a future time. Physicians and other health care providers can still be required "to assist" public health officials, but cooperation is now coerced as "a condition of licensure" instead of a legal requirement with criminal penalties for noncompliance. The quarantine provisions have been improved, with a new requirement that quarantine or isolation be imposed by "the least restrictive means necessary" and stronger dueprocess protection, including hearings and legal representation for

or NAAG, or other governmental or private agencies, departments, institutions, or organizations which have provided funding or guidance to the Center for Law and the Public's Health. This draft is prepared to facilitate and encourage communication among the various interested parties and stakeholders about the complex issues pertaining to the use of state emergency health powers."

Assuming the second cover page is accurate, the first, which claims far more support and authority for the model act than it actually had, is unprofessional and misleading in the extreme. This may be acceptable behavior for a lawyer-advocate, but is not acceptable from an academic or scholar. Nonetheless, the authors continue to overstate the extent of support for their product, writing in the summer of 2002 , for example, that " 16 states and the District of Columbia already have enacted a version of the act (as of June 26,2002 , states enacting or expected shortly to enact legislation influenced by the Model Act were Arizona, Florida, Georgia, Hawaii, Maine, Maryland, Minnesota, Missouri, New Hampshire, New Mexico, Oklahoma, South Carolina, South Dakota, Tennessee, Utah, and Virginia)." Lawrence Gostin et al. The Model State Emergency Health Powers Act: Planning for and Response to Bioterrorism and Naturally Occurring Infectious Diseases, 288 JAMA 622,622 (2002). What some of these states actually did is summarized in notes 85 and 86 infra.

The most supportive organization, the National Conference of State Legislatures, set forth its views in June 2002: "NCSL does not endorse or recommend passage of the Model State Emergency Health Powers Act. This document [the Act] and the checklist questions are provided as a service to legislators and their staff who are considering changes to state statutes regarding public health emergencies." LISA SPEISSEGGER \& CHERYL RUNYON, The Model State Emergency Health Powers Act: A Checklist of IssUES 1 (NCSL, Washington, D.C., 2002).

${ }_{77}$ Letter on file with the author, responding to the letter quoted in note 58, supra. 
those actually quarantined. Nonetheless, on the basis of a written directive by a public health official, a person can still be quarantined for 15 days before a hearing must be held, and the hearing itself can be for groups of quarantined persons rather than individuals. ${ }^{78}$ Nothing in the revised act distinguishes between approved drugs and vaccines and investigational agents, even though the latter are the most likely to be used, and even though state law cannot override federal drug laws that govern their use and informed consent requirements. ${ }^{79}$

Some of the revised quarantine provisions seem even more arbitrary. A major criticism of the original version of the act was the extreme vagueness of its standard for quarantine, which invited the arbitrary use of force. According to the original version, reproduced above, public health officials could order a person quarantined if they were "uncertain ... [whether a person who refuses to be examined or tested has] been exposed to an infectious disease or otherwise poses a danger to public health." ${ }^{, 80}$ In the revised version the standard is made even more vague. Quarantine can be ordered when the person's refusal to be examined or tested "results in uncertainty regarding whether he or she has been exposed to or is infected with a contagious or possibly contagious disease or otherwise poses a danger to public health." ${ }^{81}$ This is no standard at all, and simply permits public health authorities to quarantine anyone who refuses to be examined or treated, for whatever reason, since all refusals will result in uncertainty - if you were already certain, you wouldn't order the test. At the hearing, if requested, it seems like the standard for continued quarantine is that the individual would significantly jeopardize the public health authority's ability "to prevent or limit the transmission of a contagious or possibly contagious disease to others." ${ }^{, 82}$ This standard also makes no sense because the public health focus, I think, should be on the person's condition and on the determination of whether the person poses a danger to others, not on the public health authority's ability to function.

These vague standards are especially troublesome because the act's incredible immunity provision remains unchanged. Thus, all state public health officials and all private companies and persons operating under their authority are granted immunity from liability for their actions (except for gross negligence or willful misconduct), even in the case of death or permanent injury. Out-of-state emergency

${ }^{78} I d$., sections 605(a) and (b) at pp. 28-29.

79 Supra notes 19 to 46 and accompanying text.

${ }^{80}$ Supra note 53 and accompanying text.

${ }^{81}$ See MSEHPA Draft, supra note 76, at 26 (emphasis supplied).

${ }^{82}$ See MSEHPA Draft, supra note 76, at 30. 
health care providers have even greater protection; they are given immunity from liability for everything but manslaughter. In my opinion, such immunity is something public health authorities should not want (even though it may have superficial appeal), because it means that they are not accountable for their actions, no matter how arbitrary. The immunity provision thus serves only to undermine the public's trust in public health authorities. Citizens are not soldiers, and should never be treated against their will by their government. But if they ever are, they should be fully compensated for injuries suffered as a result. ${ }^{83}$

\section{A MODEL FOR DISASTER?}

There is no chance that every, or even many, states will adopt the suggested act as written, so if uniformity is seen as necessary or desirable, only a federal statute can provide it. Obviously, it is also much more important what states like New York and California (large states that are likely bioterror targets) do than what states like Montana, Wyoming or Arkansas do. So far, only a few states, like Delaware, Oklahoma, and South Carolina, have adopted the suggested act wholesale. More typically states have ignored it, or like California, have considered it and rejected it outright. Other states, like Minnesota, have modified their quarantine laws, but have updated them to be consistent with contemporary medical ethics and constitutional rights, rather than making them more arbitrary.

The drafters, nonetheless, continue to grossly overstate their support. In their August 7, 2002 JAMA article, for example, the act's drafters state: "Legislative bills based on the MSEHPA have been introduced in 34 states and the District of Columbia; 16 states and the District of Columbia have enacted a version of the act (as of June 26, 2002 , states enacting or expected shortly to enact legislation influenced by the Model Act were Arizona, Florida, Georgia, Hawaii, Maine, Maryland, Minnesota, Missouri, New Hampshire, New Mexico, Oklahoma, South Carolina, South Dakota, Tennessee, Utah, and

${ }^{83}$ See, e.g., George J. Annas, The Nuremberg Code in U.S. Courts: Ethics Versus. Expediency, in THE NAZI DOCTORS AND NuREMBERG CODE 201, 212-19 (George J. Annas \& Michael A. Grodin, eds., Oxford U. Press, 1992) (arguing that U.S. policy on human experimentation places human rights and ethics behind national security \& expediency). A good example of how arbitrary power tends to be used in emergencies is the use of potentially lethal gas by Russian commandos to "rescue" hostages held by Chechen nationals in October 2002. See Steven Lee Myers, From Anxiety, Fear and Hope. The Deadly Rescue in Moscow, N.Y. TIMEs, Nov. 1, 2002, at $\mathrm{Al}$ (stating that the gas killed at least 118 of the hostages). 
Virginia)." ${ }^{\prime 44}$ This is the language of salespeople, not legal scholars. It is incorrect to state that " 16 states . . have enacted a version of the act;" it is justifiable, but misleading, to state that this group of states has (or will) "enact legislation influenced by the Model Act." In fact, of the list, the following states (and the District of Columbia) rejected all or most of the language of the Act, and none of them adopted the most controversial items regarding treatment and quarantine as proposed: Georgia, Missouri, New Hampshire, New Mexico, South Dakota, Tennessee, Utah, and Virginia. ${ }^{85}$ In the cases of these bills, for the drafters of the model act to take credit for them is a bit like the old story of the rooster taking credit for the sun rising in the morning. Some states, including Florida, Maine, Maryland, New Hampshire, Hawaii, Minnesota and Arizona did adopt quarantine laws affected by the model act, but none are substantially identical to it. ${ }^{86}$ Of their list,

${ }^{84}$ See Gostin et al., supra note 76, at 622-23.

85 A detailed state-by-state comparison of the laws so far enacted is well beyond the scope or purpose of this article, and would serve little purpose. It is also difficult to generalize about this group of state statutes (except to say that they are all substantially different from the model act). Nonetheless, a few examples illustrate the range and content of these laws. Georgia provides in relevant part that the department of health shall "promulgate appropriate rules and regulations" for vaccination and isolation and quarantine "in the case of a public health emergency." S.B. $385,146^{\text {th }}$ Gen. Assem., Reg. Sess. (Ga. 2001) enacted May, 2002 and codified in GA. CODE ANN. $\S \S 31-12-3$ and 4; and $\S 38-3-51$ (i)(2)(Supp. 2002). New Mexico's entire act is only two pages long and provides for a petition to the court in case a person refuses voluntary treatment, detention or observation, and an evidentiary hearing based on clear and convincing evidence. Moreover, "The provisions of this section do not permit the forcible administration of medications." H.B. 195, 45 ${ }^{\text {th }}$ Leg., $2 \mathrm{~d}$ Sess. (N.M. 2002) codified in N.M. STAT. ANN. § 24-1-15(I.) (Michie Supp. 2002). South Dakota passed two 2 page laws dealing with emergencies; no quarantine or treatment provisions are included, but the Governor may "provide for the examination and safe disposal of any dead body as may be reasonable and necessary to respond to the disaster, emergency, or act of terrorism." H.B. 1303, $77^{\text {th }}$ Legis. Assem., Reg. Sess. (S.D. 2002) codified in S.D. CoDIfIED LAwS ANN. $§ 33-15-8$ (8) (LexisNexis Supp. 2002). Missouri's act is mostly devoted to wiretapping and communications interception, and various types of terrorism, issues not even addressed in the model act (the only provision of the model act is disaster planning and temporary licensure). S.B. 712, $91^{\text {st }}$ Gen. Assem., 2d Reg. Sess. (Mo. 2002).

${ }^{86}$ This group of laws is all over the place, ranging in anticipated coercive actions from Florida to Minnesota. Florida is perhaps the most draconian of these laws, providing that "If the individual [who refuses to be examined or treated] poses a danger to the public health, the state health officer may subject the individual to quarantine. If there is no practical method to quarantine the individual, the state health officer may use any means necessary to vaccinate or treat the individual. Any order of the state health officer given to effectuate this paragraph shall be immediately enforceable by a law enforcement officer." Florida S.B. 1262 (2002). New Hampshire, the "live free or die" state, has provisions for treatment and quarantine, but provides that "Nothing in this chapter shall be construed to require the medical ex- 
only Oklahoma and South Carolina can accurately be described as having "enacted a version of the act," and in no case is it an identical version.

Notably, under the new Minnesota law, even in a public health emergency, "individuals have a fundamental right to refuse medical treatment, testing, physical or mental examination, vaccination, participation in experimental procedures and protocols, collection of specimens, and preventive treatment programs. ${ }^{187}$ The law further requires a health care provider "where feasible" to "notify the individual of the right to refuse., ${ }^{.88}$ Of course there are extreme circumstances under which isolation or quarantine can be employed. But the Minnesota legislature permits such measures only under very limited conditions, the right to refuse all interventions continues in isolation and quarantine, and family members are specifically given the right to choose to enter the isolation or quarantine area to visit. Most of the other provisions of the suggested act, including the immunity provisions, were referred to the Minnesota commissioner of health who was instructed to study them and report back to the legislature, after having solicited public comment on any recommendations. ${ }^{89}$ The Minnesota legislature properly recognized that human rights and health are not inherently conflicting goals that must be traded off against each other. They are, as Jonathan Mann first articulated in the context of the international HIV/AIDS epidemic, "inextricably linked." ${ }^{90}$

The suggested act was drafted under extreme albeit self-imposed time constraints in the immediate aftermath of $9 / 11$ and the anthrax

amination, medical treatment, or immunization of a person who objects, and no criminal penalties shall be imposed as a result." Moreover, should quarantine be ordered, it shall be at the place of the individual's own choosing "unless the Commissioner determines such place to be impractical or unlikely to adequately protect the public health." 2002 NH H.B. 1478 (enacted May 17, 2002). Minnesota also, and even more explicitly, protects an individual's right to refuse treatment: "Notwithstanding laws, rules, or orders made or promulgated in response to a national security emergency, peacetime emergency, or public health emergency, individuals have a fundamental right to refuse medical treatment, testing, physical or mental examination, vaccination, participation in experimental procedures and protocols, collection of specimens, and preventive treatment programs." MINN. STAT. ANN. $§ 12.39$ (West Supp. 2003).

${ }^{87} \mathrm{Id}$.

${ }^{88}$ Id.

${ }^{89} \mathrm{Id}$.

${ }^{90}$ Model act drafter Lawrence Gostin used to share this belief as well. See, e.g., Jonathan M. Mann et al., Health and Human Rights, 1 HEALth AND HUMAN RIGHTS 6 (1994) (explaining collaboration among health and human rights programs). Gostin \& Mann, supra note 74. 
attacks when fear ruled reason. This is a predictable prescription for disaster. Sensible public health and bioterrorism legislation must be drafted in a calm atmosphere, in a transparent, public process. Perhaps most importantly, as Ken Wing has noted, "statute drafting is a technical and instrumental job - one that should follow, not precede the more fundamental task of deciding what the statute ought to say." "91 Public health must ultimately rely not on force but on persuasion, and never on blind trust. Trust itself must be based on transparency, accountability, democracy and human rights.

There is plenty of time to draft and debate a $21^{\text {st }}$ century federal public health law that takes constitutional rights seriously, unites the public with its medical caretakers, treats medicine and public health as true partners, and moves us in the direction of global cooperation. The revised act could be useful as a checklist for reviewing existing law, but only if it is continuously subject to scrutiny and improvement, and is rewritten to be consistent with federal statutory, regulatory and constitutional law.

\section{FEDERAL (AND GLOBAL) PUBLIC HEALTH}

A bioterrorist attack on the US is inherently a matter of national security, making it a federal, not a state, matter. Epidemics arising from outside the US are also matters of national concern. Public health policy should be national, and the addition of national security to national financing and interstate commerce, provides constitutional authority for Congress to enact legislation giving the federal government the leadership role in public health in the $21^{\text {st }}$ century. To re-

91 Kenneth Wing, The Model Act: Is It the Best Way to Prepare for the Next Public Health Emergency?, 19 NW. PUB. HEALTH 10 (2002). Epidemiologic models for responding to a smallpox attack did not begin to appear in the literature until almost a year after the model act was drafted. Controversy continues about which model is most likely to mirror reality, and all are based on assumptions about the number of people each person with smallpox is likely to affect. As one commentator put it, "Without appropriate data, models cannot indicate whether we should target contacts for quarantine or vaccination when those contacts have been made in households, schools, workplaces, at public events, or under other circumstances." Jim Koopman, Controlling Smallpox, 298 SCIENCE 1342, 1343 (2002). See also M. Elizabeth Halloran et al., Containing Bioterrorist Smallpox, 298 SCIENCE 1428 (2002). Of course, developing an effective legal strategy is dependent upon reasonable epidemiology, and without it legal plans are likely to be unresponsive or irrelevant to real world epidemics - whether naturally-occurring or terrorist-created.

The authors are currently working on yet another "model" public health act under the Turning Point Project for the Robert Wood Johnson Foundation. Speissegger \& Runyon, supra note 76 . The credibility of their new act could, of course, be severely undermined by their zealous attempts to sell this one. 
spond effectively to bioterrorism and epidemics, it is imperative that the federal government develop a national plan that individual states can help implement, and that the federal government supply the states with the badly needed financial and other resources to improve public health infrastructure, training, and coordination.

At the outset of the $21^{\text {st }}$ century, bioterrorism, although only one threat to public health, can be the catalyst to effectively federalize and integrate much of what is now uncoordinated and piecemeal state and local public health programs. This should include a renewed effort for national health insurance, national licensure for physicians, nurses, and allied health professionals, and national patient safety standards. ${ }^{92}$ Federal public health leadership will also encourage us to look outward, and to recognize that prevention of future bioterrorist attacks and even ordinary epidemics will require international cooperation. ${ }^{93}$ It is time to not only federalize public health, but to globalize it as well.

The sudden appearance of SARS (Severe Acute Respiratory Syndrome) on the world stage in February 2003 illustrates all of these points. It is a useful illustration because SARS is like a $19^{\text {th }}$ century epidemic in that there is no diagnostic test, no effective treatment, and no vaccine. Although it is far too early in this new viral epidemic to predict its outcome, a few observations can be made. First, SARS is a global epidemic. It began in China, and quickly spread throughout Asia and to North America, often by infected persons traveling by air. ${ }^{94}$ No individual country, let alone a state within a country can effectively deal with a global epidemic alone. The World Health Organization quickly (and appropriately) took the lead in responding to

${ }^{92}$ See George J. Annas, Bioterrorism, Public Health, and Human Rights, 21HEALTH AFFAIRS 94, 96 (2002) (arguing for a more federalized and global public health system, protection of basic human and constitutional rights, and modernization of public health system).

${ }_{93}$ Although I have argued in this piece that modern public health will from now on be considered primarily a federal rather than a state responsibility, it would be even better if it were treated as a global issue, since epidemic diseases know no geographic boundaries and effective public health measures demand international action. See generally, LaURIE GarReTt, Betrayal of TRUST: THE CollaPSE of Global Public Health (Hyperion, 2000) (discussing the global impact of disease); see generally InstituTE of MEDICINE, EMERGING INFECTIONS: Microbial THREATS to HEALTH IN THE UNITED STATES (Joshua Lederberg et al. eds., 1992) (noting the need for a "comprehensive global infectious disease surveillance system"); Lauren Z. Asher, Confronting Disease in a Global Arena, 9 CARDOzo J. INT'L \& COMPARATIVE L. 135 (2001) (noting the importance of international health regulations).

94 Julie Louise Gerberding, Faster .. but Fast Enough? Responding to the Epidemic of Severe Acute Respiratory Syndrome, 348 NEw ENG. J. MED. 2030 (2003). 
the epidemic by, among other things, initiating travel advisories. ${ }^{95}$ Second, sick people and their health care providers almost universally acted appropriately. Those who were diagnosed with SARS, for example, agreed to voluntary treatment and isolation, and physicians and nus sio did not try to avoid their duties (even though they were the individuals who turned out to be most at risk to contract SARS). As two U.S. public health experts put it, "praise is due to the hundreds of health care workers throughout the world who come to work every day to assist patients with SARS despite some risks to their own health." 96 Public health and medicine have been partners, not enemies, in responding to SARS.

Third, mass involuntary quarantine is generally unnecessary and almost always ineffective because it leads to mistrust of the government. In one three day period, for example, after a rumor that Beijing itself might be quarantined or put under martial law, almost a quarter of a million migrant workers fled to rural Henan province; and in a small rural town, Chagugang, thousands rioted and destroyed a building that was being finished to quarantine SARS patients. ${ }^{97}$ Mistrust of the Chinese government generally made it more difficult for China to deal with its epidemic effectively. ${ }^{98}$ A more effective strategy, employed in every affected democratic country, was to ask those people possibly infected with SARS to voluntarily stay at home for ten days and monitor their temperatures. In the United States, this method was used almost exclusively, with the exception of two tourists in New York City, and one in Dallas, who were quarantined involuntarily in hospitals because they had no home to stay in. ${ }^{99}$ No governor declared a state of emergency - so no emergency public health law was

${ }^{95}$ Margot Cohen, Gautam Naik \& Matt Pottinger, Inside the WHO as it Mobilized for War on SARS, WALL ST. J., May 2, 2003, at A1; Matt Pottinger, Elena Cherney, Gautam Naik \& Michael Waldholz, How Global Effort Found SARS Virus in Matter of Weeks, WALL ST. J., April 16, 2003, at Al; Lawrence K. Altman, W.H.O. Expected to Gain Broader Powers, N.Y. TIMES, May 28, 2003, at A10.

${ }_{96}$ Richard P. Wenzel \& Michael B. Edmond, Managing SARS amidst Uncertainty, 348 NEW ENG. J. MED. 1947, 1948 (2003).

97 Charles Hutzler, China Reverts to Top-Down Rule with Heavy Hand to Fight SARS, WALL ST. J., May 8, 2003, at A8; Leslie Chang \& Peter Wonacott, SARS Measures in China Add to Air of Panic, WALL ST. J., April 25, 2003, at B7; Erik Eckholm, SARS is the Spark for a Riot in China, N.Y. TIMES, April 29, 2003, at Al.

${ }_{98}$ John Pomfret, A Mistrust of Government Undercuts China's Effort, WASH. Post, April 29, 2003, at Al. A small authoritarian state, like Singapore, ruthlessly (and effectively) enforced quarantines. Wayne Harold, In Singapore, 1970's Law Becomes Weapon Against SARS, N.Y. TIMES, June 10, 2003, at D5.

${ }^{99}$ Lawrence K. Altman, Public Health Fears Cause Officials to Detain Foreign Tourist, N.Y. TIMES, April 28, 2003, at A15, and Marci Layton, N.Y.C. Health Dept. (personal communication, June 18, 2003). 
triggered. Finally, response to major epidemics must be federal. The only legal change in the United States in response to SARS was made by the federal government, and applies primarily to individuals arriving to the United States from areas in which SARS is present. SARS was added to the list of federal "quarantinable communicable diseases" on April 4, 2003..$^{100}$

Similar lessons about the appropriate level of government for public health planning for bioterrorism can be drawn from the preparations for a smallpox attack. The need for trust in public officials is also illustrated, since in this case (like the case of offering anthrax vaccine to those potentially exposed to anthrax) it seems to be primarily distrust of government that led the vast majority of those eligible for smallpox vaccination to refuse it. No one can quantify the risk of a smallpox bioterrorism attack; it is very low, but its potential for harm is so great should it happen that it cannot be ignored by government. ${ }^{101}$ All major discussions and planning for such an attack have been done at the federal level, especially at the CDC. ${ }^{102}$ Stockpiles of existing smallpox vaccine have been created by the federal government, tests to dilute the vaccine have been sponsored by the federal government, and the development of new smallpox vaccines is being financed by the federal government. ${ }^{103}$ All of the existing and proposed supply of smallpox vaccine will be owned and controlled by the federal government. ${ }^{104}$ Not only will the individual states have no say as to whether or not smallpox vaccine will be available to them, decisions about whom the vaccine will be available to (such as military personnel, emergency department nurses, physicians and other employees, first responders), etc., will be made by federal officials, not by governors or other state officials. The most difficult decision,

100 Executive Order 13295, Revised List of Quarantinable Communicable Diseases, April 4, 2003. See also, DHHS, Control of Communicable Diseases, 68 FED. REG. 17559 (April 10, 2003).

101 See, e.g., Gina Kolata, A Nation Challenged: Vaccinations; With Vaccine Available, Smallpox Debate Shifts, N.Y. TIMES, March 30, 2002, at A8 (stating potential harm of smallpox attack but also stating that the potential for such an attack is low).

102 E.g., CDC Smallpox Response Plan and Guidelines, Draft 3.0 (Sept. 21, 2002), at http://www.bt.cdc.gov/agent/smallpox/repsonse-plan/index.asp. See also, e.g., supra notes 37-43 and accompanying text for FDA regulation of drugs and vaccines related to a bioterrorist attack.

${ }^{103}$ Robert Pear, Frozen Smallpox Vaccine is Still Potent, Officials Say, N.Y. Times, March 30, 2002, at A8.

${ }^{104}$ Lawrence Altman, William Broad \& Denise Grady, White House Debate on Smallpox Slows Plan for Wide Vaccination, N.Y. TIMES, Oct. 13, 2002, at 10. 
whether to make smallpox vaccine available to members of the public prior to an attack, will be made by the president. ${ }^{105}$

Two points about smallpox preparation merit emphasis: first, this is a federal public health activity; ${ }^{106}$ and second, smallpox vaccination is likely to remain an entirely voluntary decision. Troops slated to go to Iraq were involuntarily vaccinated, but even this military exception was put in place only after the vaccine itself was properly licensed by the FDA, and screening was performed so that military personnel at risk of an adverse reaction were excluded. ${ }^{107}$ The military smallpox vaccination program went essentially as planned, although more than

${ }^{105}$ Id. See also Marilyn Chase and Greg Hitt, Ugly Side Effects of Smallpox Vaccine Color Terror Plans, WALL ST. J., Oct. 21, 2002, at Al (noting health and liability risks associated with the vaccine). Homeland Security Director Tom Ridge has also been quoted as saying, "The president on down-everyone-recognizes in this life-and-death decision that the president has to make, there will be some families that endure losses and others that endure permanent injury. There has to be some way to compensate them." Id. See also The Homeland Security Act, which provides that all lawsuits involving the smallpox vaccine must be filed against the federal government. H.R. 5710, $107^{\text {th }}$ Cong. \& 304(c)(p)(2)(B) (2002).

${ }_{106}$ The new Homeland Security Act, H.R. 5710, $107^{\text {th }}$ Cong. $\$ 304(c)(p)(1)-$ (2)(A)(i), (c)(p)(7)(B)-(C) (2002), made special provisions for the administration of "any substance used to prevent or treat smallpox" to civilians. Specifically, if the Secretary of Health and Human Services issues a declaration "concluding that an actual or potential bioterrorist incident or other actual or potential public health emergency makes advisable the administration" [of smallpox vaccine or treatment] a "covered person shall be deemed to be an employee of the Public Health Service with respect to liability arising out of administration of a covered countermeasure against smallpox." Covered person is defined to mean not only the "qualified person" who administers the drug or vaccine, but also the manufacturer, the health care entity under whose auspices the smallpox vaccine or treatment is administered, and any "official, agent or employee" of the manufacturer, health care entity, or person administering the treatment or vaccine. A "qualified person" (i.e., the one administering the vaccine or treatment) "means a licensed health professional or other individual who is authorized to administer such countermeasure under the law of the State in which the countermeasure was administered." All lawsuits for injury would have to be filed against the U.S. (Sec. 304)

Of course what this means for a state that adopts the provisions of the "model act" is that recovery for negligence of the individuals administering smallpox vaccine and treatment will be available (albeit, only by suing the federal government, as was the case in the 1976 swine flu vaccination program). It also means, however, that the qualifications of the people administering the treatment will be determined by state law; under the model act, whoever the public health authority designates to fill the vaccinator and/or treatment role. Congress could, of course, make different rules for agents other than those designed for smallpox, and could amend these rules as well.

${ }^{107}$ Altman et al., supra note 98, and Denise Grady, Pentagon Faces Difficulties in Smallpox Shots for Troops, N.Y. TIMES, Dec. 17, 2002, at A16. See also Lawrence K. Altman \& Sheryl Gay Stolberg, Smallpox Vaccine Backed for Public, N.Y. TIMES, Oct. 5, 2002, at Al (noting that when the vaccine is publicly available it will be offered on an optional basis). 
100 women who were pregnant were vaccinated who should have been excluded. ${ }^{108}$ The plan to vaccinate up to 500,000 health care workers who would be responsible to vaccinate the public in the event of a smallpox attack, however, faltered badly, and by June, 2003 was officially "paused." 09 Many explanations have been provided for a response rate of less than $10 \%$ of eligible physicians and nurses. The most reasonable one seems to be that both the risks and the benefits of the smallpox vaccine were exaggerated, and physicians and nurses concluded (reasonably I think) that notwithstanding the government's position, the risk of the vaccine was not worth the benefit. ${ }^{110}$

After the conclusion of the Iraq War, the public relations disaster of recommending that all Americans get a supply of duct tape and plastic sheeting, and the growing public cynicism with repeated "orange alerts," few health care workers could take the prospect of a smallpox attack seriously. ${ }^{111}$ Thus, even though the risk of the vaccine was relatively low, the benefits appeared to be even lower. In this regard, trust in what the government said was very low - I think because if the government has information about a country or group that has weaponized smallpox, it has an obligation to share this information with the American public. It is terrorists who would want to keep this information a secret, not the potential targets of an attack. Thus the federal government's failure to make their intelligence available to the public led, I think, to the reasonable conclusion that the government actually possessed no credible information - and could even have been using the smallpox scare to build support for the Iraq

${ }^{108}$ Donald McNeil, 2 Programs to Vaccinate for Smallpox are 'Paused,' N.Y. TIMEs, June 19, 2003 at A13; Denise Grady, Despite Warnings, Pregnant Women Got Smallpox Vaccine, N.Y. TiMES, May 2, 2003 at A18.

109 Id., and Richard W. Stevenson \& Sheryl Gay Stolberg, Bush Lays Out Plan on Smallpox Shots; Military is First, N.Y. TIMES, Dec. 14, 2002, at 1A. See also, Jon Cohen \& Martin Enserink, Rough-and-Tumble Behind Bush's Smallpox Policy, 298 SCIENCE 2312 (2002), and Ceci Connolly, Panel Urges Caution on Smallpox Innoculation, Washington Post, June 20, 2003, at A9.

${ }^{110}$ See generally George J. Annas, Smallpox Vaccine: Not Worth the Risk, HASTINGS CENTER REPORT, March-April 2003, at 6 (arguing that the federal government's statement that "there is not a zero risk of a smallpox attack" was "useless information" and "counterproductive" without disclosing the basis of the information because "[s]ecrecy makes sense only for the attacker, not the defenders."); Joan Stephenson, Smallpox Vaccine Program Launched Amid Concerns Raised by Expert Panel, Unions, 289 JAMA 685 (2003).

111 Id. See William J. Broad, Bush Signals He Thinks Possibility of Smallpox Attack is Rising, N.Y. TIMES, Dec. 14, 2002 at A10; Judith Miller, C.I.A. Hunts Iraq Tie to Soviet Smallpox, N.Y. TIMES, Dec. 3, 2002, at A20; Anita Manning, How Prepared are we Against Smallpox?, USA TODAY, March 6, 2003, at ID. 
War. ${ }^{112}$ Nonetheless, the conclusions regarding federal authority over public health policy related to bioterrorism, support for voluntary public health programs, and the necessity of public trust for effective public health interventions are all illustrated by our experience to date with smallpox vaccination. Reducing the risk of a smallpox attack will also require global action. Specifically, the US should take a leadership role in strengthening international treaties to prevent the manufacture, storage, and use of biological toxins. ${ }^{13}$

\section{CONCLUSION}

Our new kind of war against bioterrorism should be built on a goal of protecting liberty, not depriving Americans of it. As the American Civil Liberties Union has put it after 9/11, we should keep America "safe and free" (although I'd reverse the order). There is a knee jerk tendency in times of war and national emergencies to restrict civil liberties as the most effective way to counteract the threat. But history has taught us that such restrictions are almost always useless and often counterproductive, and we usually wind up with deep regrets for our action. ${ }^{114}$ The tendency to return to the days before liberty and informed consent were taken seriously was evident both in the Gulf War and in the immediate aftermath of 9/11. In neither instance did these responses help make Americans safer or more secure, and in both they threatened the very liberties that make our country worth protecting.

The planned use of arbitrary force by Americans against Americans is un-American, even if done in the name of public health. No American physician should be forced to do anything to a patient that the physician does not believe is in the patient's best interests, and even then only with the patient's consent. No American soldier should be forced to take experimental drugs and vaccines; and no American citizen should be forced to take any drug or vaccine, or to be quarantined against their will, when any other less restrictive alter-

112 E.g., Marie McCullough \& Marian Uhlman, National Campaign Against Smallpox Falters, PHILADELPHIA INQUIRER, April 3, 2003 at B1; Martin Ensherink, Smallpox Vaccination Campaign in the Doldrums, 300 SCIENCE 880 (2003).

${ }^{113}$ See, e.g., Bruce Alberts \& Robert M. May, Scientist Support for Biological Weapons Control, 298 SCIENCE 1135 (2002).

114 The interment of Japanese Americans during World War Il is only the most spectacular of these "emergency" civil rights violations - not only did it unfairly and unjustly impact on the Japanese involved, but its legacy made it impossible to engage in any sort of rational airport screening in the wake of 9/11. But see, Eric Lichtblau, Bush Issues Racial Profiling Ban but Exempts Security Inquiries, N.Y. TIMES, June 18, 2003 at $1 \mathrm{~A}$. 
[Vol. 13:33

native is available. America is strong because its people are free, and to be both moral and effective public planning for war and public health emergencies must be based on respecting freedom and trusting our fellow citizens. Rather than adopt the tactics of repressive totalitarian regimes, the United States should lead the world in proclaiming a new, global public health, based on transparency, trust, and science, and most importantly, based on respect for human rights. 